Applied Economics

\title{
Optimal versus adequate level of international reserves: evidence for Turkey
}

\section{Suheyla Ozyildirim \& Bülent Yaman}

To cite this article: Suheyla Ozyildirim \& Bülent Yaman (2005) Optimal versus adequate level of international reserves: evidence for Turkey, Applied Economics, 37:13, 1557-1569, DOI: $10.1080 / 00036840500166373$

To link to this article: http://dx.doi.org/10.1080/00036840500166373

曲 Published online: 15 Aug 2006.

Submit your article to this journal $\pi$

Џll Article views: 78

Q View related articles ๘

4 Citing articles: 4 View citing articles 


\title{
Optimal versus adequate level of international reserves: evidence for Turkey
}

\author{
Suheyla Ozyildirim ${ }^{\mathrm{a} * *}$ and Bülent Yaman $^{\mathrm{b}}$ \\ ${ }^{a}$ Bilkent University, Faculty of Business Administration, 06800 Bilkent, \\ Ankara, Turkey \\ ${ }^{\mathrm{b}}$ Central Bank of Republic of Turkey, Money and FX Markets, 06100 Ulus, \\ Ankara, Turkey
}

\begin{abstract}
The determination of international reserve balance for emerging economies is part of the efforts to strengthen the immunity of these economies to crises. However, there is still evidence on crises even for the countries with large foreign reserves. It has usually been experienced that the countries with greatest need for reserves economize more than others on their holdings since they might underestimate the cost of crisis. In this study, the official international reserves of Turkey are tested against optimality and adequacy. During 1988-2002, the actual reserves fell short of both the optimal and the adequate levels. They are only optimal when the expected cumulative contraction is about $5.2 \%$ of real GDP under crisis. However, early evidence from emerging economies and Turkey show that crises hit more heavily. Hence, it is found that the current financial structure in Turkey such as the absence of capital controls and a highly dollarized banking system necessitates more foreign reserves for preventing any future economic and/or financial shocks.
\end{abstract}

\section{Introduction}

The recent evidence that countries holding large reserves during the Asian crisis managed to avoid financial attacks renewed the interest on the better management of international reserves. Feldstein (1999) emphasized that emerging markets should stop depending on international organizations such as the IMF to protect themselves from currency crises but to increase their liquidity at a reasonable cost. Those who support holding a lot of reserves argue that the opportunity cost of stockpiling reserves is small compared to the economic consequences of financial crises (Aizenman and Marion, 2003) and/or exchange rate to float (Feldstein, 2002; Calvo and Reinhart, 2003). ${ }^{1}$ However earning small yields on reserves and paying higher interest on outstanding liabilities, it would be still very costly to accumulate ${ }^{2}$

\footnotetext{
*Corresponding author. E-mail: suheyla@bilkent.edu.tr

${ }^{1}$ Feldstein (2002) argues that the policymakers in Argentina were well aware of the coming crisis when they pursued the pegged exchange rate regime but in order to keep their decade of price stability, they did not allow the exchange rate to float and bear the consequence of the severe crisis in 2001.

${ }^{2}$ Feldstein (1999) mentions that for Mexico, an additional US\$30 billion in order to double its reserves would cost nearly half-of-one per cent of its GDP per year. Bird and Rajan (2003) estimates similar figure for the recent Asian crisis and found that annual cost of extra reserves is $0.3-1.0 \%$ of GDP for Indonesia, Malaysia, Philippines, Thailand and South Korea in 1999.
} 
and hold large reserves for most of the developing countries. In practice, it has been experienced that the countries with greatest need for reserves economize more than others on their holdings especially, when international markets are tight (Batten, 1982; Landell-Mills, 1989). So the real challenge for the monetary authorities of emerging markets would be to augment international reserves to the level where the estimated benefits are at least equal to the cost of holding additional balances. In this paper, the aim is to study a reserve level such that any sovereign country can optimally control both the saving of precautionary reserves and cost of idle stockpiles under risk of economic contraction.

The reserve adequacy should vary amongst developing countries depending on the economic circumstances and the health of the financial institutions. During financial panics, countries prone to capital flight will rapidly lose their reserves when investors' confidence disappears (Bird and Ramkishen, 2003). Attaining adequate or more international reserves for a heavily debted country would not be definite considering the recent evidence in Korea that large reserves did not make this country immune to financial crisis. In this study, it is stressed that in the determination of international reserve balances, monetary authorities should consider the risk of economic and/or financial turmoil and their possible impacts on their national economies.

In the literature, as an alternative to rule-of-thumb ratio analyses, international reserves are determined by optimization methods (Heller, 1966; Frenkel and Jovanovic, 1981; Landell-Mills, 1989; Ben-Bassat and Gottlieb, 1992a). Although it has been argued that optimizing approaches have operational shortcomings, they allow monetary authorities to incorporate more country specific information into consideration. A common reserve goal for all countries ignores the potential exposures to crises or attacks for a specific country. In the determination of an optimal amount of international liquidity, monetary authorities minimize the cost of undesired output contractions and foregone returns with fair prices respectively.

The paper particularly examines both the optimal and the adequate level of international reserves for Turkey during the period 1988-2002. In the settlement of optimal reserve balances, monetary authorities are assumed to consider the default risk or vulnerability to a crisis and its impact on their economy. By recent evidence from most of the emerging markets, crises were followed by downturns of GDP for a considerable period of time. Although the output has not responded uniformly across countries, there are approximate estimates of the cumulative output losses for an emerging economy. Adapting the early findings of output costs due to crisis, the vulnerability of the Turkish economy to external shocks over the sample period is estimated to determine the expected value of the cost of an attack under insufficient reserve holdings. In the empirical model of vulnerability, it is found that the exposure to economic and/or financial turmoil in Turkey is not associated with the ratio of shortterm banking debts to reserves as in many early examples ${ }^{3}$ but the ratio of capital inflows or outflows to reserves over time. Reinhart and Reinhart (1998) point out that the vulnerability of the financial sector increases for countries where the weak domestic banking system plays a dominant role in intermediating the capital flows. After 1987, Turkish commercial banks provided short-term capital inflows to the economy extensively as an intermediate for the government's short-term borrowing needs for its deficit. Ertug̃rul and Selçuk (2002) discern that this deficit financing led banks to open short positions in foreign currency and exposed them to insolvency risk due to exchange and/or interest rate shocks over the last two decades. Similarly, in the paper it is observed that the level of capital flows - in or out - with respect to international reserves is perceived as an indication of the vulnerability of Turkey.

Moreover, deposit dollarization (increasing the share of the foreign currency deposits with respect to the local currency ones) is another significant indicator of the riskiness of the Turkish economy. After the late-1980s, there is a persistent tendency of Turkish depositors to hold much of their financial wealth in foreign currency denominated deposits in order to protect their wealth against a loss in value due to high inflation and depreciation of the Turkish Lira. ${ }^{4}$ Until the last twin crisis in 2001, highly dollarized Turkish banks ${ }^{5}$ continued to collect foreign currency denominated deposits and ignored to take any prudent measures in the management of their

\footnotetext{
${ }^{3}$ In many of the recent studies about Asian crisis, there are evidences on the association of short-term banking debts and the subsequent financial crises. See Frankel and Rose (1996), Sachs et al. (1996), Edwards (1999), Kaminsky and Reinhart (1999), Radalet and Sachs (1998), Aizenman and Marion (2004).

${ }^{4}$ The average annual inflation were $71.2 \%$ over the period between 1988 and 2002 . For the same period, on average US dollar appreciates $67.5 \%$ annually against Turkish Lira.

${ }^{5}$ The share of foreign currency denominated assets (liabilities) in total assets (liabilities) increased from $26 \%$ (25\%) in 1988 to $49.2 \%(55.8 \%)$ in 2002 .
} 
assets and liabilities. ${ }^{6}$ Thus, the profitable short positions in foreign currency aggravated the vulnerability of the whole banking sector. Even though the asset substitution provides a hedge against exchange rate risk for the domestic savers, it increases the possibility of banks runs when the devaluation is impending (Honohan and Shi, 2002; De Nicoló et al., 2003). Hence, it is found that foreign investors increase their expectation on default risk of Turkey by the growing tendency of savers to hold more foreign currency denominated deposits in the domestic banks.

According to the estimate of default probability, the impact of crisis on the real economy and the opportunity cost of holding reserves, it is observed that Turkey did not hold optimal balances of foreign reserves between 1988-2002. Nevertheless, the actual level of official reserves would have been optimal with an estimated expected cumulative damage of an attack of about $5.2 \%$ of real output over the sample period. However, the last 25 years of evidence on the exposure of emerging economies to currency and/or banking crises ended with higher costs to the national economies of more than $15 \%$ of real GDP (see Bordo et al., 2001; Hutchison and Noy, 2005). Hence, it is concluded that Turkish monetary authorities should expand the level of international reserves further in order to minimize the expected costs under the threat of economic and/or financial attacks. Moreover, it is found that reserves are less than the adequate levels considering the exchange rate regime, the country risk and the early experiences in Turkey. In particular, reserves in Turkey with respect to broad money, short-term debts and/or the combination of these are found to be insufficient.

The rest of the paper is organized as follows. The theoretical model with the empirical estimations and the optimal reserves are presented in Section II. The adequate and the official amounts of international reserves for Turkey is compared in Section III. The paper concludes with comments in Section IV.

\section{A Theoretical Model for Optimum International Reserve Level}

\section{The model}

In the literature, there are many studies and reviews on the determination of international reserves starting from the 1960s. The recent paper by Bahmani-Oskooee and Brown (2002) provided a very comprehensive survey on the theoretical and empirical developments of the issue. In the theoretical models, the major concern of the monetary authority is to determine the optimal level that minimizes the net holding cost of reserves considering the risk of default of a sovereign country under unexpected economic events considering. As stated by Heller (1966), 'the optimal level of international reserves is given by the amount which minimises the total cost of adjusting and/or financing an external imbalance'. The necessity of adjustment and financing of reserves depends on the probability of any country facing future shocks. In general, there is a tradeoff between the precautionary motive of holding large reserves for external fluctuations and the forgone earnings on reserve holdings. ${ }^{7}$

In this paper, the work by Ben-Bassat and Gottlieb (1992a) is used to solve the problem of a monetary authority who governs the optimal reserve level, $R^{*}$ by minimizing the following expected cost function,

$$
\min _{R} E(T C)=(1-\pi) r R+\pi C
$$

where $T C$ is total cost and $E$ is the expectation operator. As a general simplifying convention, $T C$ is the summation of two expected costs. The first one is the expected cost of forgone returns on reserve holdings, $R$ and the second one is the expected output loss, $C$ due to the countries in economic and/or a financial crisis. By Equation 1, the monetary authority determines the optimal level of reserves by trading-off output and return losses. In the model, $\pi$ is the probability of a country's default due to economic and/or financial turmoil. ${ }^{8}$ In the previous theoretical and empirical models, the reserves and the probability of default are generally negatively related. Nevertheless, using the early evidence it is assumed that countries with large reserves defend themselves better against crisis or its contagious effect. Hence, the probability of failure can be described by

$$
\pi=f(R, \mathbf{z}) \quad \frac{\partial \pi}{\partial R}=\pi_{R}<0
$$

$\mathbf{z}$ is a vector of economic variables that determines the vulnerability or default risk of a country in international bond markets. For instance, $\mathbf{z}$ includes variables that represent the economic fundamentals such as soundness of banking system. Sachs et al. (1996) and Feldstein (1999) show that countries with a good banking system have been expected to be less exposes to external imbalances.

\footnotetext{
${ }^{6}$ See Ertug̃rul and Selçuk (2002) for the three stages of Turkish banking sector.

${ }^{7}$ See for instance Heller (1966), Frenkel and Jovanovic (1981), Landell-Mills (1989), Ben-Bassat and Gottlieb (1992b).

${ }^{8}$ Reinhart (2002) found that about $85 \%$ of all the defaults in 59 countries during $1970-1999$ are linked with currency crisis.
} 
In order to incorporate the impact of economic and/or financial collapse into the total cost function, the cumulative response of national output before and after crisis is considered. Although there are some contradicting empirical evidences ${ }^{9}$ on the adverse impact of crises on economic growth, the general outcome of economic and/or financial failures for emerging markets is an output contraction for a period of time. Bordo et al. (2001) concludes that over the last 120 years, crises have been followed by downturns lasting on average 2 to 3 years and costing 5 to 10 per cent of GDP. After the economic and/or financial turmoil, there will be a slowdown in the future flows of foreign credit and imported goods to the domestic market and this will cause a setback in growth of output for a while. In the paper, the cumulative output losses, $C$ is measured by using the previous empirical findings on the output cost of crises in emerging markets.

The overall opportunity cost of holding a given amount of international reserves is a function of its volume, $R$ and the net opportunity cost of forgone returns, $r{ }^{10}$ The measure for cost of holding reserve or foregone returns differ amongst emerging countries depending on their economic circumstances. Especially, for the countries prone to crisis or heavily debted, $r$ will be more critical in the determination of optimal reserve level. Since these countries mostly accumulate reserves by internationally borrowing instead of giving trade surpluses, the interest rates charged to them, $r$ increase significantly. Hence, they may choose to economize more instead of augmenting the reserve level at some adequate level.

From the total cost function which is the summation of the expected cost of failure, $\pi C$ and the opportunity cost, $(1-\pi) r R$ the first order condition of the problem (Equation 1) is

$$
\frac{\partial E(T C)}{\partial R}=-\pi_{R} r R+(1-\pi) r+\pi_{R} C=0
$$

such that the optimal reserve balance depends on the cost of failure, net opportunity cost and the absolute and the marginal default probabilities at given reserve level

$$
R^{*}=\frac{\left(1-\pi\left(R^{*}\right)\right)}{\pi_{R}\left(R^{*}\right)}+\frac{C}{r}
$$

Since there is no explicit theoretical relation between reserves and default probability, the empirical association of these variables is used in the determination of $R^{*}$. In the following subsection, the cost and the probability of failure for Turkey will be estimated to calculate the optimal reserves described in (Equation 3). Thus, the optimal foreign currency holdings of the Turkish monetary authorities will be hypothesized during 1988-2002 period.

\section{Estimation and results}

Cost of failure. In the period of economic and/or financial turmoil, a country might suffer a serious decline in output. Yet, the degree of this fall back is influenced by the initial economic conditions of the specific country, the crisis management and the rescue packages provided by the international organizations (see Gupta et al., 2003; Dooley and Verma, 2001). In the literature, there is still no single or best way of measuring the output loss during crises (Bordo et al., 2001). Hutchison and Noy (2005) argue that there is also a paucity of empirical work related to the output loss due to various crises. In the determination of the output cost of crises for Turkey, the statistical estimates provided by Hutchison and Noy (2005) in a panel data set for emerging economies over 1975-1997 is applied. ${ }^{11}$

Ben-Bassat and Gottlieb (1992a) determine the cost of failure by regressing the six years of discounted output forgone to openness (import-to-output ratio) for 13 countries over $1960-1982$ period and find that the cumulative loss or the difference between potential and actual output over six-years period

\footnotetext{
${ }^{9}$ For instance, Gupta et al. (2003) find that in a sample of 278 currency crises across 125 countries between the 1970 s and 1990 s, over $40 \%$ of crises have been expansionary.

${ }^{10}$ Since reserves have interest income, the opportunity cost is net of this value.

${ }^{11}$ In the sample, periods of twin crisis are highlighted with bold letters: Banking Crises: Argentina (1980-1982, 1989-1990, 1995-1997), Brazil, (1990, 1994-1997), Chile (1976, 1981-1983), China (1982-1986), Columbia (1982, 1987), Costa Rica (1987, 1994-1997), Indonesia (1994, 1997), Jordan (1989-1990), Korea (1997), Malaysia (1985-1988, 1997), Mauritius (1996), Mexico (1981-1991, 1995-1997), Panama (1988-1989), Philippines (1981-1987, 1997), Singapore (1982), South Africa (1977, 1985, 1989), Thailand (1983-1987, 1997), Trinidad and Tobago (1982-1993), Tunisia (1991-1995), Turkey (1982-1985, 1991, 1994-1995), Uruguay (1981-1984), Venezuela (1978-1986, 1994-1997). Currency Crises: Argentina (1975-1976, 1982-1983, 1989-1991), Brazil (1982-1983, 1987, 1990-1991, 1995), Chile (1985), Columbia (1985), Costa Rica (1981), Indonesia (1978, 1983, 1986, 1997), Jordan (1983, 1987-1989, 1992), Korea (1980, 1997), Malaysia (1986, 1997), Malta (1992, 1997), Mauritius (1979, 1981), Mexico (1976, 1982, 1985, 1994-1995), Philippines (1983-1984, 1986, 1997), Singapore (1975), South Africa (1975, 1978, 1984-1986, 1996), Thailand (1981, 1984, 1997), Trinidad and Tobago (1985, 1988, 1993), Tunisia (1993), Turkey (1978-1980, 1994), Uruguay (1982-1983), Venezuela (1984, 1986, 1994-1996).
} 
after default increases significantly for a country with heavy trade flows. However, no statistically significant relation between loss of output and openness is observed when the date is updated and the same model is regressed. Moreover, the duration of crisis on the real economy decreases for the financially open economies further ${ }^{12}$ that the empirical findings of Hutchison and Noy (2005) is studied to determine the cost of output loss for Turkey.

In Hutchison and Noy (2005), real output growth is regressed with lagged output growth, domestic policy factors (changes in government budget surplus and credit growth), structural factors (openness), external factors (growth in foreign output and real exchange rate overvaluation), and country specific weighted average growth rate over the sample period of past 25 years. ${ }^{13}$ According to their results, currency (banking) crises reduce output by about 5-8 (8-10)\% over two-four year period. Thus, in the calculation of the optimal reserve levels for Turkey, the output loss will be 1.27-2.06 (2.06-2.60)\% in each quarter related to currency (banking) crisis. Moreover, since it is found that annual output declines by $13-18 \%$ due to the combined effect of the two crises, the quarterly fall of output is about $3.42-4.84 \%$ due to twin crisis. In a similar study by Bordo et al. (2001) including both the industrial and emerging economies, the cumulative output losses are measured for the 1973-1997 period by 13\% of GDP for currency and banking crises in total, and 16\% for twin crises. In summary, the optimal level of international reserves for Turkey is calculated considering the impact of $5-18 \%$ of output contractions due to various types of crises. ${ }^{14}$

Probability of failure. In order to compute the subjective probability of failure, the premium paid on government's foreign currency borrowings is used to measure country risk (see Edwards, 1984; Gottlieb, 1989; Landell-Mills, 1989; Ben-Bassat and Gottlieb, 1992a). The financial markets assess the default probabilities and reflect these risks by charging a higher premium or spread on foreign borrowing of a sovereign country. Thus, the spread is the difference between the interest rate, $i$ charged to a risky country and the riskless country loan rate or LIBOR, $i^{*}$. According to expectations theory, the investors' view of the expected probability of default of an individual country to the creditors is extracted as, ${ }^{15}$

$$
(1-\pi)(1+i)=\left(1+i^{*}\right)
$$

where it is assumed that the lender requires an expected return on risky country loan equal to at least the risk-free return. ${ }^{16}$ More explicitly, under a competitive loan market, the discounted expected profit of a risk neutral lender will be zero. ${ }^{17}$ Hence, the relation between the spread, $i-i^{*}$ and the failure probability, $\pi$ will be as follows

$$
i-i^{*}=\frac{\pi}{1-\pi}\left(1+i^{*}\right)
$$

Thus, for a given value of risk-free rate, spread increases for a country with higher risk, $\pi .^{18}$

According the recent studies on the determination of the vulnerability of developing countries, the popular indicative factors like current account deficit, debt/export ratios, fiscal deficits, rate of inflation etc. do not appear to be significant anymore. ${ }^{19}$ In particular, it has been evidenced that crises are spreading mainly to the countries with weak banking and low liquid reserves with respect to external and internal liabilities. In the light of these studies. Table 1 summarizes the result of the regression analysis for the determination of spread reflecting the international credit risk of Turkey.

In this empirical analysis, it is identified that shortterm capital flows to reserves $(\mathrm{STCF} / R)$, the ratio

\footnotetext{
${ }^{12}$ See Calvo and Reinhart (2000) for the empirical evidences on the average duration it takes to return to 'normal' after currency and banking crises.

${ }^{13}$ See Hutchison and Noy (2005) for the details of the model and how their formulation avoids various biases. The model is mainly estimated by Hausman and Taylor procedure and the robustness tests with other methods such as LSDV and GMM are also provided in the paper.

${ }^{14}$ These figures might underestimate the loss of output over time. In the period of general slow down, the impact of crisis on the cumulative loss will be small since GDP has already declined.

${ }^{15}$ The similar analyses have been done for the determination of credit risk or expected default rate for corporate bonds and loans in the financial intermediation market. See Altman and Arman (2002) for the calculation of default probabilities and risk premiums for different risk-rated corporations in each year for US market.

${ }^{16}$ It is assumed that loans are one year maturity.

${ }^{17}$ Under perfect competition, risk neutral investor's US\$1 turns either $i$ discounted with safe rate, $i^{*}$ or zero. Thus, the expected profit, $(1-\pi)\left(-1+\left[(1+i) /\left(1+i^{*}\right)\right]\right)+\pi(-1+0)$ is zero where $\pi$ is the probability of default. See Appendix in Gottlieb (1989) for the further discussions.

${ }^{18}$ Gottlieb (1989) explicitly derived Equation 5 under a competitive loan market where both the lenders and the borrowers are risk neutral.

${ }^{19}$ For instance, see Frankel and Rose, 1996; Sachs et al., 1996; Kaminsky and Reinhart, 1999; Aizenman and Marion, 2004.
} 
Table 1. Probability of failure, 1988Q1-2002Q4 dependent variable: $\ln \left(i-i^{*}\right) /\left(1+i^{*}\right)$

\begin{tabular}{lcrr}
\hline & & \multicolumn{2}{l}{$t$-values } \\
\cline { 3 - 4 } & Coefficient & OLS & GMM \\
\hline Intercept & -3.4482 & -3.90 & -2.69 \\
$\exp (\mathrm{STCF} / R)$ & 1.2808 & 2.33 & 1.67 \\
$\ln (\mathrm{FCD} / \mathrm{LCD})$ & 1.2761 & 4.91 & 3.85 \\
$\ln ($ Import $/ \mathrm{GNP})$ & -0.8812 & -2.25 & -1.94 \\
Adjusted $R^{2}$ & 0.3134 & & \\
D.W. & 0.8570 & & \\
$F$-value & 9.98 & & \\
Prob $>F$-value & $<0.0001$ & & \\
\hline
\end{tabular}

Note: $\pi$ is derived from Equation 5 as $\ln \left(i-i^{*}\right) /\left(1+i^{*}\right)=$ $\ln \pi /(1-\pi)$.

of foreign currency to domestic currency deposits of banks $(\mathrm{FCD} / \mathrm{LCD})$ and the average propensity to import (Import/GNP) significantly explain the risk perception of the foreign lenders in the Turkish Eurobond market during $1988-2002 .{ }^{20}$ It is found that the variables in the estimated risk premium equation are at the expected signs. The relationship between ratio of short-term capital flows to reserves and spread is positive as expected. It has been widely evidenced that financial capital can depart just as rapidly as they arrived so, there is a genuine risk on them leading to severe macroeconomic instabilities (Calvo et al., 1996; Summers, 2000). In Turkey, cross-border financial flows are in general shortterm, volatile and mostly intermediated by domestic banks. After 1989, commercial banks which were the main source of demand for the government debt instruments, played a significant role in the shortterm financing of the government. However, the existence of generous deposit insurance for both local and foreign currency deposits and weak banking supervision in Turkey, commercial banks ignored risk management at their own peril. ${ }^{21}$ Especially profitable short positions during the sample period and mismatches between the currency denomination of bank loans and the currency denomination of incomes of the local business increased their vulnerability (see Reinhart and Reinhart, 1998; Ertug̃rul and Selçuk, 2002). As seen in Table 1, increase in the short-term capital flows - whether in or out with respect to international reserves is considered as an indication of increasing financial vulnerability. Since the major proportion of these capitals flows were intermediated by the fragile banks of Turkey during the sample period, it is found that risk premium on foreign borrowings of Turkey increases with the increase in the flows of gross capital stock.

Furthermore, it is found that deposit dollarization has significant influence in the measurement of the probability of failure for Turkey. Since the 1980s, domestic savers were allowed to hold foreign currency denominated deposits. Generally, the ratio of foreign to local currency deposits overestimates the dollarization impact on the domestic market since it ignores the non-bank holdings of financial instruments. Yet, $\mathrm{FCD} / \mathrm{LCD}$ is significant in determining the risk premiums on Turkish Eurobonds. De Nicoló et al. (2003) empirically show that financially dollarized economies are exposed to both solvency and liquidity risks. When there is an anticipation of devaluation, this will weaken the solvency of both banks and the borrowers. In particular, the credit risk deriving from a significant devaluation may increase the risk of deposit withdrawals by concerned depositors (liquidity risk) and lead to bank runs. Hence, the deposit and eventually asset dollarization of banks in weak currency economies such as in Turkey increase the vulnerability of the whole financial system. In the paper, it is found that increasing propensity of domestic savers to hold more foreign currency denominated deposits during the sample period significantly indicates the vulnerability of the domestic economy to various shocks. Hence, the premium charged on the financial instruments of Turkey in the international markets is higher.

In the empirical model to estimate the probability of failure, various traditional variables such as debt/export ratio, debt/reserve ratio, government expenditures to output ratio, average propensity to invest, rate of inflation, currency account deficit, etc. are also studied but no explanatory relation is found during the sample period. Only the ratio of imports to GNP which is generally known as the proxy for marginal propensity to import and/or the degree of openness weakly explains the risk premiums on the foreign borrowings. An increase in the trade relations with the rest of the world has mitigating impact on the borrowing rates in the international arena.

\footnotetext{
${ }^{20}$ Because of the existence of autocorrelation in the OLS regression, the same model is estimated by GMM where the significance of short-term capital flows to reserves and import/GNP ratio decease to 20 and $11 \%$ level respectively.

${ }^{21}$ After 1994, the partial explicit deposit insurance coverage was extended to full insurance for all domestic deposits including the foreign currency denominated ones. However, the common perception in the public is that there has been a blanket guarantee in Turkey after 1994.
} 
Therefore, the adjusted spread equation which will be used to approximate the probability of default is as follows

$$
\begin{aligned}
\ln \left(\frac{i-i^{*}}{1+i^{*}}\right)= & -3.4482+1.2808 \mathrm{e}^{\mathrm{STCF} / R} \\
& +1.2761 \ln \left(\frac{\mathrm{FCD}}{\mathrm{LCD}}\right) \\
& -0.8812 \ln \left(\frac{\text { Import }}{\mathrm{GNP}}\right)
\end{aligned}
$$

Using Equations 5 and 6, the change in probability of default by an increase in reserves (marginal probability of default) is derived as

$$
\frac{\partial \pi}{\partial R}=\pi_{R}=-\pi(1-\pi) \frac{\mathrm{STCF}}{R^{2}} 1.2808 \mathrm{e}^{\mathrm{STCF} / R}<0
$$

Equation 7 suggests that for a given balance of international reserves at time $t$, the marginal probability of failure increases as long as the capital is flowing out $(\mathrm{STCF}<0)$.

Optimal level of international reserves for Turkey. In two previous subsections the cost and the probability of failure for Turkey is determined. Using these estimates, the optimal level of reserves in 1988Q1-2002Q4 is calculated by substituting Equations 6, 7, the output loss, $C$ and the opportunity cost, $r$ into Equation 3. As mentioned before, for the countries accumulating reserves by borrowing internationally instead of running trade surplus, the opportunity cost will be significant for the determination of the optimal balances. Although the opportunity cost varies in most empirical analysis of foreign reserves, ${ }^{22}$ international borrowing rates are assumed to be the appropriate cost measure for Turkey (see Table A1 in Appendix).

The optimal reserve paths considering the possible impacts of currency, banking and twin crises on real output are reported respectively in Fig. 2 (see forward, see also Table A1. During 1988Q1-2002Q4, it is found that the official reserves mostly fall short of optimal amounts. It is apparent that even though there has been an increasing trend in the accumulation of international reserves since the currency crisis in 1994, there are few episodes where the official reserves are also optimal. ${ }^{23}$ Still, the actual reserves considering the $5 \%$ loss on national output due to currency crisis, move very close to the optimal path (see upper panel in Fig. 1). More precisely, starting from the first quarter of 1988 to the last quarter of 2002, the accumulated official reserves by the Central Bank would be considered as optimal only if the expected cumulative loss of output due to crisis were about $5.2 \%$ with given opportunity cost for Turkey. ${ }^{24}$ However, the recent crises in the last 25 years ended with more output losses in national economies. Hence, this amount might be interpreted as an indication of inadequate reserve holding of the monetary authorities in Turkey during 1988-2002 period.

Yet, this result is hypothesized statistically in order to test whether the official, $R$ and the calculated optimal reserves, $R^{*}$ are pairwise significantly different-for all crises episodes during the sample period. Thus, the optimal behaviour of monetary authorities to avoid currency, banking or twin crises at reasonable cost is examined. First, the difference, $d_{t}$ between $R_{t}$ and $R_{t}^{*}$ at time $t$ is calculated. Then, it is hypothesized that if the official and the optimal reserves do not differ significantly, the mean change, $\bar{d}(=\Sigma d / n)$ will be zero, $\mathrm{H}_{0}: \bar{d}=0$. According to $t$-statistics reported in Table 2, on average, the official and the optimal reserves are not pairwise same except for one case. The hypothesis that $\bar{d}=0$ fails to be rejected at $10 \%$ significance level for the currency crisis with real GDP loss of 5\%. However, under the threat of economic and/or financial crisis with output cost of more than $5 \%$, the optimal balances for Turkey are found to be short of the official levels.

\section{Adequate Level of International Reserves}

In the early analyses, the reserve-to-imports ratio was part of the reserve management policies.

\footnotetext{
${ }^{22}$ For instance, Ben-Bassat and Gottlieb (1992a) provide empirical evidence using Israel economy that the difference between the real return on capital and reserves measures the opportunity cost properly. They justify that this definition is in accordance with the theoretical meaning. On the other hand, Landell-Mills (1989) argues the opposite that the theoretical definition underestimates the cost for the countries with debt-servicing difficulty. When reserves are borrowed, the borrowing rates will be higher than the marginal returns on domestic investment. Yet, when reserves are not borrowed, but the government guarantees international liabilities, the value of these liabilities to the monetary authorities is so high for the sake of country's credit standing that they pay off external debt before investing domestically.

${ }^{23}$ Strikingly, over all quarters of 2001, the official reserves are above the optimal levels. This result might be misleading since there was significant decline in real GDP (almost $24.5 \%$ ) due to twin crisis in that year.

${ }^{24}$ If a constant proportion of GDP losses due to crisis is defined as $\gamma$, then $\gamma$ which makes the official reserves on average optimal is derived from Equation 3 as $\gamma=\left[R-(1-\pi) /\left(\pi_{R} r\right)\right](r / Y)$ when $Y$ is real GDP.
} 

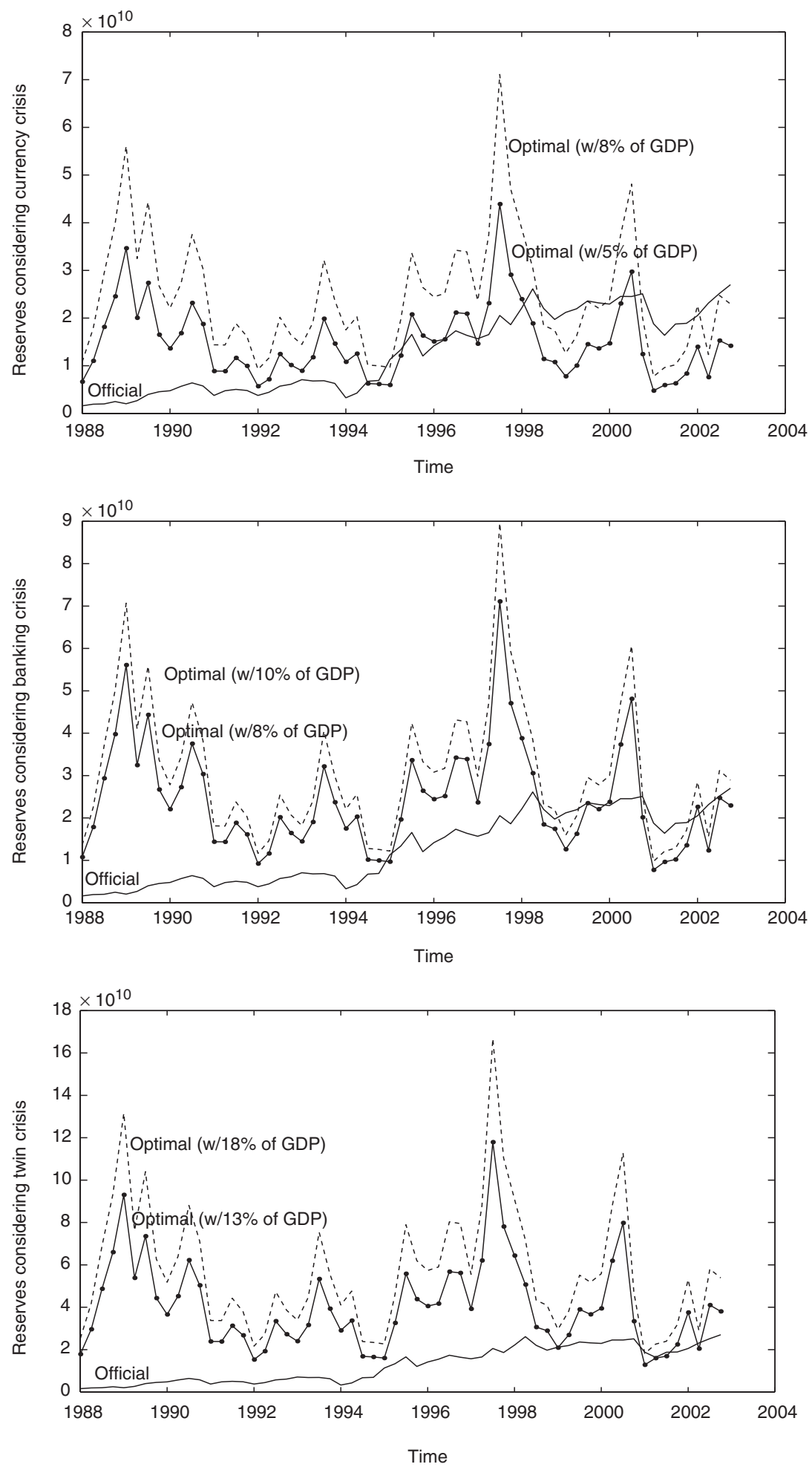

Fig. 1. Optimal versus official reserve levels

Although the rationale for using this scaling was never fully justified, it is still used in the reserve adequacy discussions especially for the countries at early stages of development that have no significant access to international financial markets (De Beaufort Wijnholds and Kapteyn, 2001; Bird and Ramkishen, 2003). In recent practices, reserve adequacy measures basically are influenced by the internal and external 


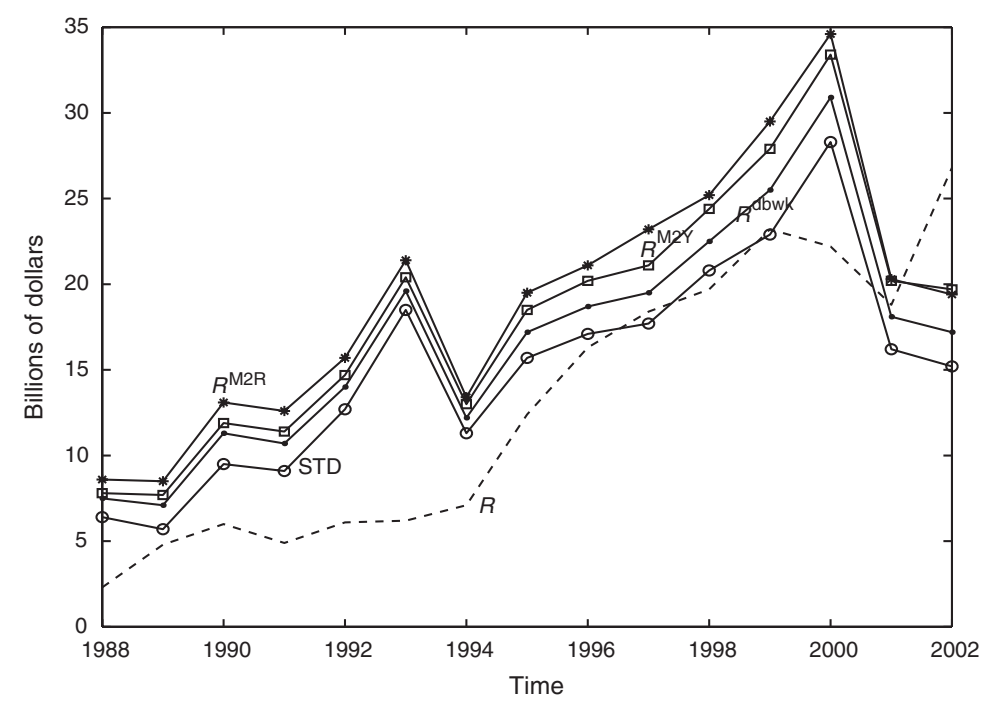

Fig. 2. Rule-of-thumb adequacy measures and short-term debts

Table 2. Paired-difference experiment for $R$ and $R^{*}, H_{0}: \bar{d}=0(n=60)$

\begin{tabular}{|c|c|c|c|c|c|}
\hline & \multicolumn{5}{|c|}{ Real GDP loss due to } \\
\hline & \multicolumn{3}{|c|}{ Currency or banking crisis } & \multicolumn{2}{|c|}{ Twin crisis } \\
\hline & $5 \%$ & $8 \%$ & $10 \%$ & $13 \%$ & $18 \%$ \\
\hline$s_{d}=\frac{\Sigma^{d^{2}}-\left(\Sigma^{d}\right)^{2} / n}{n-1}\left(\times 10^{9}\right)$ & 10.692 & 14.231 & 16.993 & 21.495 & 29.636 \\
\hline$s_{\bar{d}}=\frac{s_{n}}{(n)^{1 / 2}}\left(\times 10^{9}\right)$ & 1.380 & 1.837 & 2.194 & 2.775 & 3.826 \\
\hline$t=\frac{\bar{d}}{s_{\bar{d}}}$ & 1.681 & -6.335 & -8.196 & -9.979 & -11.618 \\
\hline
\end{tabular}

drain of financial assets during crises. Hence, reserveto-broad money, reserve-to-short-term debts and/or the combination of these two ratios become the significant determinants of international reserve adequacy for emerging economies.

Broad money (M2) and short-term-debts (STD) are used to assess the potential demand for foreign assets from domestic and foreign sources respectively. Yet the level of adequate reserves depends on the foreign exchange policies, capital controls and various other financial states of the economies. In Fig. 2, three rule-of-thumb adequacy measures for Turkey are presented. In the first measure, which is suggested by De Beaufort Wijnholds and Kapteyn (2001), the adequate level of reserve balance is found by summing total short-term debts (similar to Guidotti rule) with a certain fraction of M2 adjusted with country risk. ${ }^{25}$ The $10-20 \%$ of M2 is proposed as the expected internal drain in the countries with managed floated exchange rate regime like in Turkey. ${ }^{26}$ The summation of shortterm debts and $10 \%$ of M2 adjusted with the Turkey's country risk is reported as $R^{\mathrm{dbwk}}$ in Fig. 2. It is apparent that during 1988-2002, the official reserves, $R$ are below $R^{\mathrm{dbwk}}$. Moreover, Turkey's official reserves were lower than her short-term debt (STD) obligations until 1997. Later in 1997-1999, $R$ was barely sufficient for foreign debts but still inadequate with respect to $R^{\mathrm{dbwk}}$. After $2001, R$ is above $R^{\mathrm{dbwk}}$.

\footnotetext{
${ }^{25}$ As suggested by De Beaufort Wijnholds and Kapteyn (2001), the country risk for Turkey is obtained from the Economic Intelligence Unit of The Economist.

${ }^{26}$ De Beaufort Wijnholds and Kapteyn (2001) argues that it is 5-10\% for floating exchanged regimes.
} 

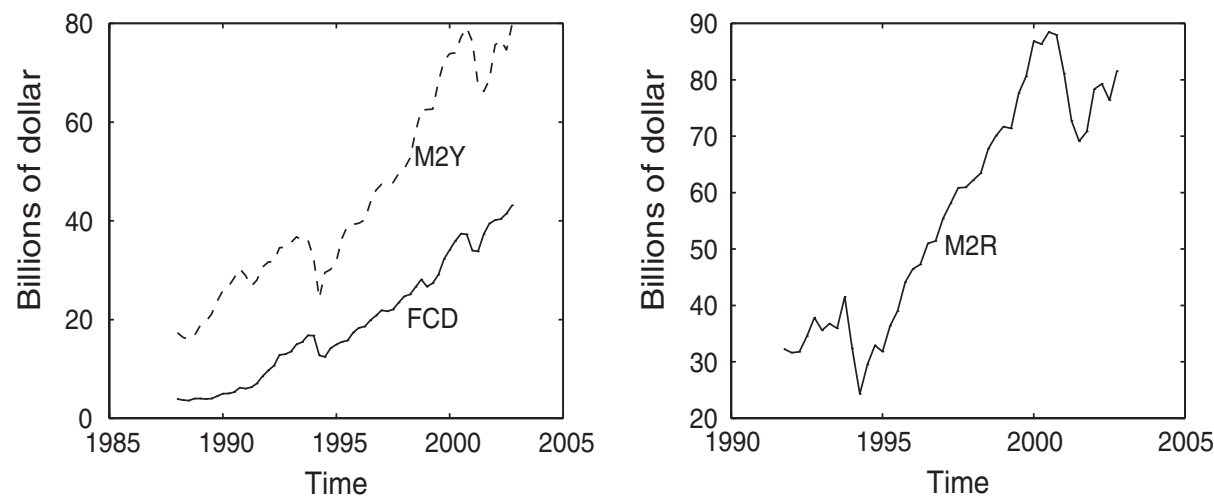

Fig. 3. M2Y with foreign currency deposits (FCD) and M2R

The other two rule-of-thumb adequacy measures are computed with the summation of total shortterm debts and certain proportion of different money aggregates. Feldstein (1999) emphasizes that the amount of convertible foreign currency deposits in commercial banks has to be considered in order to ensure sufficient international liquidity for the risk of capital flight by domestic residents. Here, M2Y which is the summation of M2 and foreign currency denominated deposits, is found an appropriate monetary aggregate to measure the internal drain of foreign currency under crisis threat. It has been experienced that M2Y declined significantly during the last two crises of Turkey. In the second quarter of 1994, the contraction on M2Y was about $24 \%$ whereas it was about $10 \%$ in aggregate, starting from the last quarter of 2000 to the second quarter of 2001 (see Fig. 3). The smaller flight in 2001 crisis can be explained by the existence of full deposit insurance guarantee even to the foreign currrency deposits after 1994. Although the deposits are hedged against both the liquidity and the exchange rate risks, fear of freezing of the deposit accounts caused the 10\% contraction of $\mathrm{M} 2 \mathrm{Y}$ in $2001 . R^{\mathrm{M} 2 \mathrm{Y}}$ is calculated by summing the total short-term debts with $10 \%$ of M2Y. Similarly the official reserves are clearly below the adequate amounts, $R^{\mathrm{M} 2 \mathrm{Y}}$ (see Fig. 2).

Lastly, $R^{\mathrm{M} 2 \mathrm{R}}$ is calculated as another ruleof-thumb adequacy measure for Turkey. In the monetary aggregate called M2R, Repurchase Agreements (Repos) are added to M2. Since the introduction in 1991, Repos have a considerable share in the monetary aggregates of Turkey. During 1991-2002, the proportion of Repos to time deposits (local currency denominated ones) were about $40 \%$. Hence, it is considered that the measurement of domestic capital flight using $\mathrm{M} 2 \mathrm{R}$ will be quite practical. Using again the recent experiences of crisis in Turkey, it is found that the contraction in M2R and Repos were about $20 \%$ and $50 \%$ respectively in both crises (see Fig. 3). Thus, $R^{\mathrm{M} 2 \mathrm{R}}$ which is obtained by summing $100 \%$ of STD and $20 \%$ of M2R is compared with the official international reserves of Turkey during 1988-2002 period. Once again, it is concluded that the actual foreign reserves are less than the adequate levels.

\section{Conclusion}

In this paper, the official international reserves of Turkey is tested against optimality and adequacy. The optimal time path of the reserves for any sovereign country is determined using the theoretical model á la Ben-Bassat and Gottlieb (1992a). In the empirical study, the model is modified for Turkey. Thus, in the estimation of probability of failure under insufficient amount of reserve holdings, it is found that the factors related to financial markets, especially the banking sector fragility explain the riskiness of Turkey in the view of international investors. In particular, increasing deposit dollarization in the saving institutions and gross capital flows - in or out - significantly indicate the vulnerability of Turkey. According to the estimated default probabilities, opportunity cost of holding reserves and the cumulative cost of failure under crisis, the optimal reserve level for each quarter of 1988-2002 is derived. It is observed that the actual amounts are mostly less than the optimal levels. More precisely, the actual reserves are only optimal when the expected cumulative contraction is about $5.2 \%$ of real GDP under crisis. However, the early evidence in emerging economies and Turkey show that crises hit more heavily. Hence, it is found that the current financial structure in Turkey such as no capital control and highly dollarized banking system necessitates more foreign reserves for preventing any future shocks. 
Moreover, three rule-of-thumb adequacy amounts are computed considering mainly the domestic and foreign capitals flights during crisis periods. The similar results are obtained that the official reserves fall short of the adequate levels during the sample period. The determination of international reserves for emerging economies is part of the efforts to strengthen these economies' immunity to crises. It has been usually experienced that the countries with greatest need for reserves economize more than others on their holdings since they might underestimate the cost of crisis. Turkey is also another example of a country that has to improve her reserves to provide international confidence.

\section{Acknowledgements}

The first author is indebted to Daniel Gottlieb for his guidance and encouragement. The authors also wish to thank Fatih Özatay, Akil Özçay, Erdal Özmen, Hakan Berument, Zeynep Önder, Yavuz Günalay, and Emrah Ekşi for their helpful comments and suggestions. The view expressed are ours and are not necessarily shared by the Central Bank of Republic of Turkey or any of its staff.

\section{References}

Aizenman, J. and Marion, N. (2003) Foreign exchange reserves in East Asia: why the high demand?, FRBSF Economic Letter, 2003-11, 1-3.

Aizenman, J. and Marion, N. (2004) International reserve holdings with sovereign risk and costly tax collection, Economic Journal, 114, 569-91.

Altman, E. I. and Arman, P. (2002) Defaults and returns on high yield bonds: analysis through 2001, Journal of Applied Finance, 12, 98-112.

Batten, D. S. (1982) Central bank's demand for foreign reserves under fixed and floating exchange rates, Federal Reserve Bank of St. Louis, March, 20-30.

Bahmani-Oskooee, M. and Brown, F. (2002) Demand for international reserves: a review article, Applied Economics, 34, 1209-26.

Ben-Bassat, A. and Gottlieb, D. (1992a) Optimal international reserves and sovereign risk, Journal of International Economics, 33, 345-62.

Ben-Bassat, A. and Gottlieb, D. (1992b) On the effect of opportunity cost on international reserves holdings, Review of Economics and Statistics, 74, 329-32.

Bird, G. and Ramkishen, R. (2003) Too much of good thing?: the adequacy of international reserves in the aftermath of crises, The World Economy, 26, 873-91.

Bordo, M., Eichengreen, B., Klingebiel, D. and MartinezPeria, M. S. (2001) Is the crisis problem growing more severe?, Economic Policy, 16, 53-82.

Calvo, G. A., Leiderman, L. and Reinhart, C. M. (1996) Inflows of capital to developing countries in the 1990s, Journal of Economic Perspectives, 10, 123-39.
Calvo, G. A. and Reinhart, C. M. (2000) When capital inflows come to a sudden stop: consequences and policy options, in Key Issues in Reform of the International Monetary and Financial System (Eds) P. Kenen and A. Swoboda, International Monetary Fund, Washington DC, pp. 175-201.

Calvo, G. A. and Reinhart, C. M. (2003) Fear of floating, Quarterly Journal of Economics, 117, 379-408.

De Beaufort Wijnholds, J. O. and Kapteyn, A. (2001) Reserve adequacy in emerging market economics, IMF Working Paper No. 143.

De Nicoló, G., Honohan, P. and Ize, A. (2003) Dollarization of banking system: good and bad?, World Bank Policy Research Working Paper No. 3116.

Dooley M. P. and Verma, S. (2001) Rescue packages and output losses following crises, NBER Working Paper No. 8315.

Edwards, S. (1984) LDC foreign borrowing and default risk: an empirical investigation, 1976-80, American Economic Review, 74, 726-34.

Edwards, S. (1999) Crisis prevention: lessons from Mexico and East Asia, NBER Working Paper No. 7233.

Ertug̃rul A. and Selçuk F. (2002) Turkish economy: 1980-2001, in Inflation and Disinflation in Turkey (Eds) A. Kibritçiog̃lu, L. Rittenberg and F. Selçuk, Ashgate Publishing Company, Aldergate, pp. 13-40.

Feldstein, M. (1999) A self-help guide for emerging markets, Foreign Affairs, 78, 93-109.

Feldstein, M. (2002) Argentina's fall, Foreign Affairs, 81, 8-14

Frankel, J. A. and Rose, A. K. (1996) Currency crashes in emerging markets: an empirical treatment, Journal of International Economics, 41, 351-66.

Frenkel, J. A. and Jovanovic, B. (1981) Optimal international reserves: a stochastic framework, Economic Journal, 91, 507-14.

Gottlieb, D. (1989) On the determinants of a country's creditworthiness: the case of Israel, Journal of Economic Development, 14, 65-91.

Gupta, P., Mishra, D. and Sahay, R. (2003) Output response to currency crises, IMF Working Paper No. 230

Heller, H. R. (1966) Optimal international reserves, Economic Journal, 76, 296-311.

Honohan, P. and Shi, A. (2002) Deposit dollarization and the financial sector in emerging economies, World Bank Working Paper No. 2748.

Hutchison, M. and Noy, I. (2005) How bad are twins? Output costs of currency and banking crises, Journal of Money, Credit and Banking, forthcoming.

Kaminsky, G. L. and Reinhart, C. M. (1999) Twin crises: the causes of banking and balance-of-payments problem, American Economic Review, 89, 473-500.

Landell-Mills, J. M. (1989) The demand for international reserves and their opportunity cost, IMF Staff Papers, 36, 708-32.

Radalet, S. and Sachs, J. D. (1998) The East Asian financial crises: diagnosis, remedies, prospects, Brookings Papers on Economic Activity, 1999-1, 1-90.

Reinhart, C. M. (2002) Credit ratings, default, and financial crises: evidence from emerging markets, World Bank Economic Review, 16, 151-70.

Reinhart, C. M. and Reinhart, V. R. (1998) Some lessons for policy makers dealing with the mixed blessing 
of capital inflows, in Capital Flows and Financial Crises (Ed.) M. Kahler, Council on Foreign Relations, New York, pp. 93-127.

Sachs, J. D., Tornell, A. and Velasco, A. (1996) Financial crises in emerging markets: the lessons from 1995 ,
Brookings Papers on Economic Activity, 1996, 147-215.

Summers, L. (2000) International financial crises: causes, preventions and cures, American Economic Review Papers and Proceedings, 90, 1-16.

\section{Appendix}

Table A1. Simulation results

\begin{tabular}{|c|c|c|c|c|c|c|c|}
\hline$t$ & $\pi$ & $\pi_{R}$ & $r$ & GDP & $R$ & $R_{5 \%}^{*}$ & $R_{18 \%}^{*}$ \\
\hline 1988Q1 & $\begin{array}{l}0.254 \\
0.197 \\
0.222 \\
0.147\end{array}$ & $\begin{array}{r}-0.011 \\
0.015 \\
0.030 \\
0.020\end{array}$ & $\begin{array}{l}0.035 \\
0.025 \\
0.020 \\
0.011\end{array}$ & $\begin{array}{l}19.390 \\
20.825 \\
29.011 \\
19.683\end{array}$ & $\begin{array}{l}1.593 \\
1.924 \\
1.983 \\
2.480\end{array}$ & $\begin{array}{r}7.042 \\
10.646 \\
18.551 \\
22.442\end{array}$ & $\begin{array}{l}26.752 \\
40.441 \\
70.473 \\
85.253\end{array}$ \\
\hline 1989Q1 & $\begin{array}{l}0.129 \\
0.166 \\
0.233 \\
0.171\end{array}$ & $\begin{array}{r}0.017 \\
0.001 \\
-0.002 \\
0.000\end{array}$ & $\begin{array}{l}0.007 \\
0.014 \\
0.017 \\
0.023\end{array}$ & $\begin{array}{l}18.919 \\
20.477 \\
29.196 \\
20.376\end{array}$ & $\begin{array}{l}2.020 \\
2.661 \\
3.982 \\
4.537\end{array}$ & $\begin{array}{l}36.086 \\
18.683 \\
21.767 \\
11.123\end{array}$ & $\begin{array}{r}137.084 \\
70.973 \\
82.689 \\
42.255\end{array}$ \\
\hline 1990Q1 & $\begin{array}{l}0.195 \\
0.218 \\
0.244 \\
0.198\end{array}$ & $\begin{array}{l}-0.010 \\
-0.008 \\
-0.003 \\
-0.004\end{array}$ & $\begin{array}{l}0.025 \\
0.025 \\
0.027 \\
0.028\end{array}$ & $\begin{array}{l}20.952 \\
23.205 \\
31.020 \\
22.148\end{array}$ & $\begin{array}{l}4.761 \\
5.685 \\
6.398 \\
5.759\end{array}$ & $\begin{array}{r}10.857 \\
11.726 \\
14.604 \\
9.928\end{array}$ & $\begin{array}{l}41.242 \\
44.543 \\
55.478 \\
37.713\end{array}$ \\
\hline 1991Q1 & $\begin{array}{l}0.142 \\
0.225 \\
0.250 \\
0.247\end{array}$ & $\begin{array}{l}0.010 \\
0.001 \\
0.009 \\
0.004\end{array}$ & $\begin{array}{l}0.043 \\
0.046 \\
0.052 \\
0.050\end{array}$ & $\begin{array}{l}20.860 \\
23.094 \\
32.245 \\
21.990\end{array}$ & $\begin{array}{l}3.766 \\
4.756 \\
5.046 \\
4.813\end{array}$ & $\begin{array}{l}6.173 \\
6.350 \\
7.856 \\
5.584\end{array}$ & $\begin{array}{l}23.451 \\
24.124 \\
29.844 \\
21.213\end{array}$ \\
\hline 1992Q1 & $\begin{array}{l}0.266 \\
0.403 \\
0.460 \\
0.408\end{array}$ & $\begin{array}{r}0.007 \\
-0.021 \\
-0.004 \\
-0.004\end{array}$ & $\begin{array}{l}0.070 \\
0.060 \\
0.052 \\
0.053\end{array}$ & $\begin{array}{l}22.573 \\
24.401 \\
33.970 \\
23.190\end{array}$ & $\begin{array}{l}3.768 \\
4.438 \\
5.715 \\
6.107\end{array}$ & $\begin{array}{l}4.097 \\
5.179 \\
8.323 \\
5.560\end{array}$ & $\begin{array}{l}15.563 \\
19.673 \\
31.617 \\
21.120\end{array}$ \\
\hline 1993Q1 & $\begin{array}{l}0.435 \\
0.448 \\
0.550 \\
0.473\end{array}$ & $\begin{array}{r}-0.012 \\
-0.009 \\
-0.006 \\
0.003\end{array}$ & $\begin{array}{l}0.048 \\
0.044 \\
0.037 \\
0.040\end{array}$ & $\begin{array}{l}23.682 \\
27.164 \\
36.488 \\
25.137\end{array}$ & $\begin{array}{l}7.080 \\
6.805 \\
6.863 \\
6.277\end{array}$ & $\begin{array}{r}6.231 \\
7.805 \\
12.509 \\
8.009\end{array}$ & $\begin{array}{l}23.671 \\
29.649 \\
47.521 \\
30.425\end{array}$ \\
\hline 1994Q1 & $\begin{array}{l}0.449 \\
0.368 \\
0.388 \\
0.422\end{array}$ & $\begin{array}{l}0.017 \\
0.022 \\
0.009 \\
0.003\end{array}$ & $\begin{array}{l}0.034 \\
0.025 \\
0.082 \\
0.073\end{array}$ & $\begin{array}{l}24.912 \\
24.261 \\
33.641 \\
23.756\end{array}$ & $\begin{array}{l}3.271 \\
4.257 \\
6.741 \\
6.906\end{array}$ & $\begin{array}{r}9.398 \\
12.353 \\
5.214 \\
4.160\end{array}$ & $\begin{array}{l}35.700 \\
46.925 \\
19.806 \\
15.803\end{array}$ \\
\hline 1995Q1 & $\begin{array}{l}0.529 \\
0.379\end{array}$ & $\begin{array}{l}-0.014 \\
-0.003\end{array}$ & $\begin{array}{l}0.065 \\
0.041\end{array}$ & $\begin{array}{l}24.539 \\
27.545\end{array}$ & $\begin{array}{l}11.292 \\
13.350\end{array}$ & $\begin{array}{l}4.811 \\
8.581\end{array}$ & $\begin{array}{l}18.276 \\
32.598\end{array}$ \\
\hline 1995Q3 & $\begin{array}{l}0.393 \\
0.295\end{array}$ & $\begin{array}{r}-0.001 \\
0.004\end{array}$ & $\begin{array}{l}0.035 \\
0.034\end{array}$ & $\begin{array}{l}36.661 \\
25.329\end{array}$ & $\begin{array}{l}16.572 \\
12.043\end{array}$ & $\begin{array}{r}13.407 \\
9.416\end{array}$ & $\begin{array}{l}50.931 \\
35.769\end{array}$ \\
\hline 1996Q1 & $\begin{array}{l}0.375 \\
0.366 \\
0.382 \\
0.322\end{array}$ & $\begin{array}{r}-0.003 \\
-0.003 \\
0.001 \\
0.000\end{array}$ & $\begin{array}{l}0.029 \\
0.032 \\
0.035 \\
0.030\end{array}$ & $\begin{array}{l}26.666 \\
29.771 \\
38.601 \\
27.111\end{array}$ & $\begin{array}{l}14.162 \\
15.481 \\
17.332 \\
16.386\end{array}$ & $\begin{array}{l}11.547 \\
11.784 \\
14.039 \\
11.666\end{array}$ & $\begin{array}{l}43.864 \\
44.765 \\
55.329 \\
44.317\end{array}$ \\
\hline 1997Q1 & $\begin{array}{l}0.298 \\
0.352 \\
0.374 \\
0.312\end{array}$ & $\begin{array}{r}0.001 \\
-0.002 \\
0.000 \\
0.001\end{array}$ & $\begin{array}{l}0.031 \\
0.024 \\
0.018 \\
0.022\end{array}$ & $\begin{array}{l}28.510 \\
32.293 \\
41.316 \\
29.222\end{array}$ & $\begin{array}{l}15.685 \\
16.524 \\
20.535 \\
18.610\end{array}$ & $\begin{array}{l}11.637 \\
17.475 \\
29.662 \\
16.976\end{array}$ & $\begin{array}{r}44.207 \\
66.385 \\
112.680 \\
64.489\end{array}$ \\
\hline 1998Q1 & $\begin{array}{l}0.363 \\
0.342 \\
0.339 \\
0.429\end{array}$ & $\begin{array}{r}-0.001 \\
0.000 \\
0.002 \\
-0.004\end{array}$ & $\begin{array}{l}0.021 \\
0.030 \\
0.072 \\
0.064\end{array}$ & $\begin{array}{l}31.144 \\
33.342 \\
42.418 \\
28.860\end{array}$ & $\begin{array}{l}22.097 \\
26.134 \\
22.020 \\
19.718\end{array}$ & $\begin{array}{r}19.154 \\
14.092 \\
7.487 \\
5.703\end{array}$ & $\begin{array}{l}72.762 \\
53.534 \\
28.441 \\
21.666\end{array}$ \\
\hline 1999Q1 & $\begin{array}{l}0.313 \\
0.303 \\
0.358 \\
0.306\end{array}$ & $\begin{array}{l}0.000 \\
0.000 \\
0.000 \\
0.000\end{array}$ & $\begin{array}{l}0.059 \\
0.053 \\
0.052 \\
0.044\end{array}$ & $\begin{array}{l}28.596 \\
32.612 \\
39.765 \\
28.254\end{array}$ & $\begin{array}{l}21.193 \\
21.937 \\
23.587 \\
23.177\end{array}$ & $\begin{array}{l}6.213 \\
7.814 \\
9.723 \\
8.123\end{array}$ & $\begin{array}{l}23.600 \\
29.683 \\
36.936 \\
30.860\end{array}$ \\
\hline
\end{tabular}


Table A1. Continued

\begin{tabular}{|c|c|c|c|c|c|c|c|}
\hline$t$ & $\pi$ & $\pi_{R}$ & $r$ & GDP & $R$ & $R_{5 \%}^{*}$ & $R_{18 \%}^{*}$ \\
\hline 2000Q1 & $\begin{array}{l}0.314 \\
0.332 \\
0.398 \\
0.360\end{array}$ & $\begin{array}{r}-0.001 \\
0.000 \\
0.000 \\
-0.001\end{array}$ & $\begin{array}{l}0.033 \\
0.025 \\
0.027 \\
0.054\end{array}$ & $\begin{array}{l}30.200 \\
34.871 \\
42.884 \\
30.670\end{array}$ & $\begin{array}{l}22.926 \\
24.547 \\
24.530 \\
25.097\end{array}$ & $\begin{array}{r}11.655 \\
17.785 \\
20.278 \\
7.172\end{array}$ & $\begin{array}{l}44.275 \\
67.564 \\
77.034 \\
27.245\end{array}$ \\
\hline 2001Q1 & $\begin{array}{l}0.260 \\
0.278 \\
0.459 \\
0.411\end{array}$ & $\begin{array}{l}0.001 \\
0.004 \\
0.001 \\
0.003\end{array}$ & $\begin{array}{l}0.086 \\
0.069 \\
0.085 \\
0.055\end{array}$ & $\begin{array}{l}29.900 \\
31.458 \\
39.661 \\
27.500\end{array}$ & $\begin{array}{l}18.796 \\
16.379 \\
18.751 \\
18.892\end{array}$ & $\begin{array}{l}4.449 \\
5.813 \\
5.935 \\
6.405\end{array}$ & $\begin{array}{l}16.902 \\
22.081 \\
22.545 \\
24.332\end{array}$ \\
\hline 2002Q1 & $\begin{array}{l}0.416 \\
0.401 \\
0.454\end{array}$ & $\begin{array}{l}0.000 \\
0.000 \\
0.001\end{array}$ & $\begin{array}{l}0.033 \\
0.071 \\
0.043\end{array}$ & $\begin{array}{l}30.524 \\
34.271 \\
42.804\end{array}$ & $\begin{array}{l}20.520 \\
23.139 \\
25.171\end{array}$ & $\begin{array}{r}11.767 \\
6.167 \\
12.538\end{array}$ & $\begin{array}{l}44.700 \\
23.428 \\
47.631\end{array}$ \\
\hline 2002Q4 & 0.429 & 0.000 & 0.044 & 30.628 & 27.006 & 8.847 & 33.608 \\
\hline
\end{tabular}

Note: Reserves, $R$ and GDP are in billions of dollars. $R_{i \%}^{*}$ denotes the optimal reserves when the expexted loss of GDP is $i$. Source: The Central Bank of Republic of Turkey. 